American Journal of Biotechnology and Biochemistry 4 (1): 19-23, 2008

ISSN 1553-3468

(C) 2008 Science Publications

\title{
Comparison Effects of Sucrose and Date Palm Syrup on Somatic Embryogenesis of Date Palm (Phoenix dactylifera L )
}

\author{
Abdullatif Alkhateeb \\ Date Palm Research Center, King Faisal University, P.O. Box 420 \\ Alhassa 31982, Kingdom of Saudi Arabia
}

\begin{abstract}
The effect of different concentration of date palm syrup (2, 4, 6, 8 and 10\%) and sucrose at concentration of 30 and $60 \mathrm{~g} / \mathrm{l}$ in addition to the control (without carbon source) on the micro propagation of date palm "cv. Suckary" were investigated. The results indicated that date syrup was taken up from the media as shown by the increase in total dry weight of culture. Addition of sucrose at $60 \mathrm{~g} / \mathrm{l}$ produced the highest number of somatic embryos and longest shoot equal to that produced by date syrup at concentration of $6 \%$ without significant differences. On the other side, sucrose at $30 \mathrm{~g} / \mathrm{l}$ improved the germination of somatic embryos followed by date syrup at $6 \%$. Regarding fresh and dry weights, adding 6\% date palm syrup was superior in this respect. Tissues grown on medium supplement with $10 \%$ of date syrup caused severe reduction in number of somatic embryo possibly due to the osmotic stress. In addition, tissues grown on medium containing $2 \%$ of date syrup had the lowest number of embryos. Date palm tissues are capable of utilizing date syrup as the sole carbon source for vegetative growth. It can be concluded that, adding date syrup locally known as 'Dibs' to the culture medium of date palm at concentration of $6 \%$ can be used totally as a replacement of sucrose which was the normally sugar used in most of plant tissue culture medium. This is the first report on the use of date syrup on somatic embryogenesis of date palm cv. Suckary.
\end{abstract}

Key words: Date syrup, dibs, sucrose, tissue culture, date palm, Phoenix dactylifera

\section{INTRODUCTION}

Date palm (Phoenix dactylifera $\mathrm{L}$.) is the major fruit crop in the Kingdom of Saudi Arabia. Its ability to tolerate adverse environmental conditions, made the arid climate of Saudi Arabia quite unique for its cultivation. The estimated annual production of dates in Saudi Arabia is 830000 tons occupying an area of 140000 hectares $(\mathrm{FAO})^{[1]}$. It is well known that date palm is propagated sexually through seeds and vegetatively by offshoot ${ }^{[2]}$. Tissue culture is a recent technique mainly used for rapid propagation of several perennial fruit trees including date palm. Normally, date palm is propagated in vitro by two methods: the first method is by embryogenesis in which vegetative embryos can continuously be formed from embryogenic callus. The second procedure is organogenesis which produces date palm buds that eventually gives plantlets without passing through the callus stage ${ }^{[3]}$.

Plant cell, tissue or organ culture normally requires a carbohydrate supply in order to satisfy energy demands. It is well known in plant tissue culture a continuous supply of carbohydrates is essential, because the photosynthetic activity of in vitro plant tissues is reduced due to low light intensity, high relative humidity and limited gas exchange ${ }^{[4]}$. Sucrose is probably the most widely used carbohydrate and carbon source in plant tissue culture media as indicated by numerous studies ${ }^{[5,6]}$. In tissue culture, carbohydrates act as osmotic agents to support the growth of tissues.

It has been reported that in many plant species adding of plant extracts juice of coconut, tomato, potato, onion, banana, orange, apple, pineapple and yeast to the culture medium enhanced the growth of tissues $^{[7-11]}$. Kinnersley and Henderson ${ }^{[12]}$ found that addition of corn (maize) syrup to basic culture media improves embryogenesis of wild carrot. In a comparison of the effects of adding coconut water, banana extract, pineapple juice or tomato juice to the Nitsch medium. Tomato juice followed by coconut water had the best effect on growth and differentiation of Cymbidium longifolium ${ }^{[13]}$.

In a study to determine the effects of natural extracts (coconut water, date palm merstimatic tissues extract and casein hydrolysate) on the growth of date palm cv. Sewi tissue culture grown in vitro. El-Assar et al. ${ }^{[14]}$

Corresponding Author: $\quad$ Abdullatif Alkhateeb, Date Palm Research Center, King Faisal University, P.O. Box 420, Alhassa 31982. KINGDOM OF SAUDI ARABIA. 
found that date extract was superior to other natural extracts in producing growing tissues that were longer, larger in diameter, and more highly coloured. Also, Puchooa and Ramburn ${ }^{[15]}$ found that, the increasing in fresh weight, dry weight and moisture content of the explants with increasing concentration of carrot juice in the medium was much lower when compared to either the cytokinin benzyladenine (BA) and/or the auxin.

Although there are data on the effect of different plant extracts on in vitro plant culture, no data are currently available for the use of date syrup on date palm tissue culture or other plants. The aim of this study was to investigate using date syrup as a substitute for sugars (especially sucrose) and to determine the optimum level of date syrup in enhancing somatic embryogenesis of date palm cv. Sukary in vitro.

\section{MATERIALS AND METHODS}

The present study was conducted in the Tissue Culture Lab. of the Date Palm Research Center, King Faisal University, Kingdom of Saudi Arabia. Date palm offshoots "cv. Sukary" approximately three-four years old and weighing 5-7 kg were separated from healthy mother trees. Offshoots were thoroughly cleaned and outer leaves were carefully removed to expose the shoot tip and lateral bud region. The exposed region was excised and immediately placed in antioxidant solution containing $150 \mathrm{mg} / \mathrm{l}$ ascorbic acid and $100 \mathrm{mg} / \mathrm{l}$ citric acid. The shoot tip and lateral buds were sterilized in $20 \%$ sodium hypochlorite (domestic bleach) containing 2-3 drops of Tween-20 for $15 \mathrm{~min}$, followed by rinsing 3 times with distilled water. The tissues were kept in the antioxidant solution until explants excision for culturing was done. In order to form embryogenic callus, culture were transferred in 3 media described as below:

1. MS media supplemented with $100 \mathrm{mg} / \mathrm{l} 2,4-\mathrm{D}$ and 3 $\mathrm{mg} / \mathrm{l}$ 2ip for culture initiation medium. Culture were incubated at $25 \pm 2^{\circ} \mathrm{C}$ in darkness for 9 weeks.

2. MS media supplemented with $10 \mathrm{mg} / \mathrm{l} \mathrm{NAA}$ and 30 $\mathrm{mg} / \mathrm{l}$ 2ip for culture swelling medium. Culture were incubated at $25 \pm 2{ }^{\circ} \mathrm{C}$ in a $16 \mathrm{~h}$ photo period provided from cool white florescent lamps for 3 weeks only.

3. MS media supplemented with $10 \mathrm{mg} / \mathrm{l} \mathrm{NAA}$ and 6 $\mathrm{mg} / \mathrm{l}$ 2ip for embryogenic callus formation. Culture were incubated at $25 \pm 2{ }^{\circ} \mathrm{C}$ in a $16 \mathrm{~h}$ photo period provided from cool white florescent lamps for 16 weeks only. Media $\mathrm{pH}$ was adjusted to 5.7 and sterilized by autoclaving for $15 \mathrm{~min}$ at $121^{\circ} \mathrm{C}$. Cultures were transferred to fresh media at 4 week intervals. The resultant embryogenic callus used for the experiment.
The modified MS media was supplemented with sucrose at concentration 0,30 and $60 \mathrm{~g} / \mathrm{l}$ and different concentrations of date syrup $(2,4,6,8$ and $10 \%)$. Cultures were incubated at $25 \pm 2^{\circ} \mathrm{C}$ in $16 \mathrm{~h}$ of light daily supplied by $65 / 80$ Warm White Weisse 3500 fluorescent tubes. Each treatment was represented by 10 replicates for completely randomized design. After 6 weeks from the onset of the experiment, several growth parameters were measured. Number of embryos, number of germinating embryos, length of embryo, fresh and dry weights were determined.

Data were statistically analyzed according to the technique of analysis of variance (ANOVA) for the completely randomized design according to Gomez and Gomez $^{[16]}$. The treatment means were compared using least significant difference (LSD) at $5 \%$ level of probability. All computations and statistical analysis was performed using the facility of computer and SAS software package ${ }^{[17]}$.

\section{RESULTS AND DISCUSSION}

Data presented in Fig. (1) revealed that sucrose at $60 \mathrm{~g} / \mathrm{l}$ and date syrup "Dibs" at $4 \%$ and $6 \%$ produced the highest number of embryos and were not significantly different from each other whereas control (without carbon source) and date syrup "Dibs" at 10\% produced the lowest number of embryos and were not significantly different from each other. Also, the results indicated that sucrose at $30 \mathrm{~g} / \mathrm{l}$ significantly enhanced the number of germinating embryos followed by date syrup "Dibs" at $6 \%$ with no significant different. Sucrose at $60 \mathrm{~g} \mathrm{l}^{-1}$ gave the longest embryo $(0.99 \mathrm{~cm})$, compared to the other treatments followed by date syrup "Dibs" at 2 and 6\% with significantly different. These results were in agreement with those obtained by some investigators ${ }^{[12,14]}$.

Regarding fresh weight, data presented in Fig. (2 A) indicated that adding date syrup at $6 \%$ produced the heaviest fresh weight of cultures (8.127 g) compared with the other treatments.

Date syrup at $8 \%, 6 \%$ and sucrose at $60 \mathrm{~g} / \mathrm{l}$ produced the highest amount of dry weight and were not significantly different from each other (Fig. 2, B).

The results indicated that date syrup was taken up from the medium, as shown by the increase in total dry weight of culture. Similar results were obtained in other studies related to adding of plant extracts juice of coconut, tomato, potato, onion, banana, orange, apple, pineapple and yeast to the culture medium ${ }^{[7,9,10,11,18]}$. 


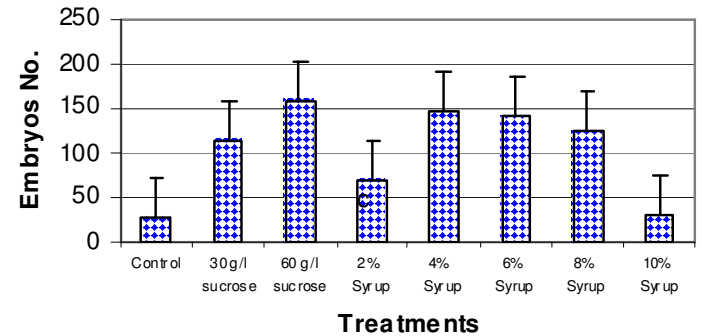

(A)

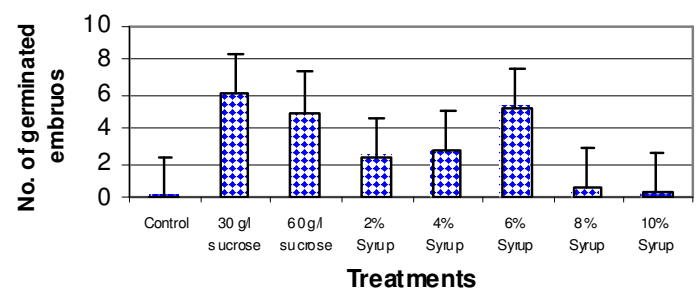

(B)

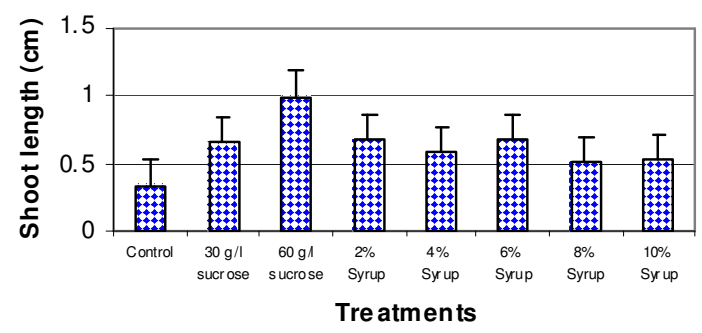

(C)

Fig. 1: Effect of different concentrations of sucrose and date syrup on number of somatic embryogenesis and its germinated and shoot length of date palm cv Suckary. Bars=LSD 0.05

As indicated previously, most of the vegetative growth characteristics measured becomes enhanced with increasing date syrup in the medium up to $6 \%$. We recorded a decrease in number of embryos and germinating embryos and an increase in fresh and dry weights of plant in response to high date syrup concentration (8 and 10\%). The substantial increased in term of fresh and dry weight at the higher concentration of date syrup along with low production of embryos raise that the increase in fresh and dry weight could be attributed to sugar accumulation rather than tissue growing. Therefore, the result indicated that the tissues may use the accumulation of sugar to reduce osmotic potential in order to withstand the high date syrup concentration in the medium, at the expense of vegetative growth.

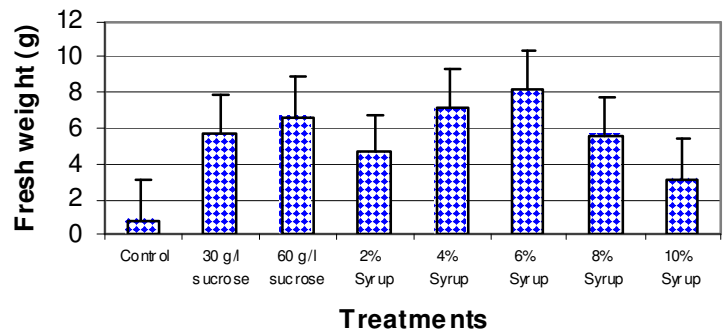

(A)

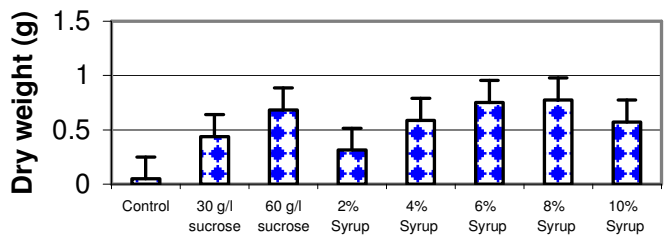

Treatments

Fig. 2: Effect of different concentrations of sucrose and date syrup on number of fresh and dry weights of plantlets date palm cv Suckary in vitro. Bars $=$ LSD 0.05

In the present study, the importance of sugar for embryos formation was clearly shown as indicated by the reduction of embryogenesis formation in the medium supplements without carbon source or low date syrup concentration $2 \%$. It seems that there was apparently insufficient sugar available in such concentrations of date syrup, which led to a reduction in vegetative growth. The reason for the superior effect from media with date syrup at $6 \%$ was presumably that tissues would not need to expend energy to break down sucrose into monosaccharide. Suad-Al-Hooti et al. ${ }^{[19]}$ reported that glucose and fructose are the major sugars presented in date syrup and total sugar contents were reaching $88 \%$. This is in accordance with findings that sucrose is degraded in to smaller units before uptake into cells in culture ${ }^{[20]}$. Alternatively date syrup contains in addition to sugar, macro and micro elements (Table 1) which may contribute to the enhancement effect of date syrup in micro propagation of date palm. 
Am. J. Biochem. \& Biotech., 4 (1): 19-23, 2008

Table 1: The constitution of date palm syrup

\begin{tabular}{lc}
\multicolumn{1}{c}{ Components } & Value \\
\hline Moisture content (\%) & 16 \\
Ash content (\%) & 6.8 \\
Total solids on dry weight (\%) & 84.0 \\
Total sugar (\%) & 79.45 \\
Reduced sugar (\%) & 4.87 \\
Invert sugar (\%) & 74.83 \\
Total proteins (as N) (\%) & 0.83 \\
Total lipids (fats) (\%) & 1.98 \\
Pectin content (as calcium pectate) & 1.46 \\
(\%) & 0.185 \\
Vit. C. content (mg/100 g) & \\
Minerals (mg/100 g) & \\
Sodium & 13 \\
Potassium & 202.8 \\
Iron & 7.8 \\
Magnesium & 143 \\
Calcium & 338 \\
\hline
\end{tabular}

It can be concluded that Date palm tissues are capable of utilizing date syrup as the sole carbon source for vegetative growth. Furthermore, date syrup at concentration of $6 \%$ can be used totally as a replacement of 30 or $60 \mathrm{~g} / \mathrm{l}$ sucrose which was the normal sugar used in most of plant tissue culture including date palm. It is well known that date syrup contains minerals and vitamins in addition to sugars (Table 1). Therefore, further experiments that look into the effect of date syrup and agar only on the tissue culture of plants are needed. Such experiments would be beneficial to those who are interested in the production of plant tissue culture. If such experiments succeed, this will reduced the cost of the production of plants tissue culture.

\section{REFERENCES}

1. FAO 2004. Food and Agriculture Organization. Year Book

2. Alkhateeb, A.A.; Aljaber, A.M.S. and Aljabr, A.M.H. 2006. Date palm in Kingdom of Saudi Arabia. The National Date Palm Research Center, Ministry of Agriculture, Kingdom of Saudi Arabia, pp. 136

3. Alkhateeb, A.A. and Ali-Dinar, H.M. 2002. Date palm in Kingdom of Saudi Arabia: Cultivation, Production and Processing. Translation, Authorship and Publishing Center, King Faisal University, Kingdom of Saudi Arabia. pp. 188
4. Kozai, T. 1991. Micropropagation under photoautotrophic conditions. In: Micro-propagation: Technology and Application. (pp 447-469). Ed: Debergh, P.C., and Zimmermann, R.H. Kluwer Academic Publishers, Dordercht

5. Vuke, T.M. and Mott, R.L. 1987. Growth of loblolly pine callus on a variety of carbohydrate sources. Plant Cell Rep. 6: 153-156

6. Alkhateeb, A.A. 2001. Influence of different carbon sources and concentrations on in vitro root formation of date palm (Phoenix dactylifera $\mathrm{L}$.) cv Khanezi. Zagazig J. Agric. Res. 28: 597-608

7. Chen, T.; Qing, Y.S. and Wei, L. 2005. The orthogonal test of induction and proliferation of Dendrobium nobile protocrom-like bodies (PLBs). Journal of South China Agricultural University 26: $60-63$

9. He, S.L.; DeZheng, K.; Qiu, Y.S. and QiXiang, Z. 2003. Effect of carbon sources and organic compounds on the multiplication of Oncidium aloha var. Iwanaga protocorm-like body. Journal of Henan Agricultural University 37: 154-157

10. Hong, E.Y.; Jong, Y.S.; IkHwan, K.; Tae, Y.; CheolHee, L.; TaeSu, K. and KeeYoeup, P. 2003. Growth, flowering, and variation of somaclones as affected by subcultures and natural materials supplemented to media in Phalaenopsis. Korean Journal of Horticultural Science \& Technology 21: 362-368

11. Amo-Marco, J. B. and Picazo, I. 1994. In vitro culture of albedo tissue from fruits of Citrus sinensis cv. Washington Navel: effect of fruit age and orange juice. Journal of Horticultural Science 69: 929-935

12. Kinnersley, A.M. and Henderson, W.E. 1988. Alternative carbohydrates promote differentiation of plant cells. Plant Cell, Tissues and Organ Culture, 15: $3-16$

13. Siddique, A. B. and Paswan, L. 1998. Effect of growth regulators and organic supplements on differentiation of Cymbidium longifolium protocorm in vitro. Journal of Hill Research 11: 234-236

14. El-Assar, A.M., W.M. El-Messeih and M.R. ElShenawi 2004. Applying of some natural extracts and growth regulators to culture media their effects on Sewi cv. date palm tissues grown in vitro. Assuit J. Agric. Sci. 35: 155-168 
15. Puchooa, D. and Ramburn, R. 2004. A study on the use of carrot juice in the tissue culture of Daucus carota. African Journal of Bio-technology 3: 248252

16. Gomez, K. A. and Gomez A. A. 1984. Statistical procedures for Agricultural research. $2^{\text {nd }}$ Ed. John Wally \& Sons

17. SAS Institute 2001. SAS for Windows, SAS user's guide: Statistics. Version 8.0 e. SAS Inst., Inc., Cary, North Carolina.

18. Lo, S.F.; Nalawade, S.M.; Chao, K.L.; Chung, C.L. and Hsin, T.S. 2004. Asymbiotic germination of immature seeds, plantlet development and ex vitro establishment of plants of Dendrobium tobaense Makino - a medicinally important orchid. In Vitro Cellular \& Developmental Biology Plant 40: 528535.
19. Suad-Al-Hooti, N.; Sidhu, J.S.; Al-Saqer, J.M. and Amani, A. 2002. Chemical composition and quality of date syrup as affected by pectinase/cellulose enzyme treatment. Food Chemistry 79: 215-220.

20. Fowler, M.W. 1982. Substrate utilization by plantcell culture. J. Chem. Tech. and BioTech. 32: 338346. 